\title{
PELATIHAN PENULISAN PROPOSAL PENELITIAN TINDAKAN KELAS (PTK)
}

\author{
Oleh: \\ Ady Soejoto', Dhiah Fitrayati', Muhammad Abdul Ghofur ${ }^{3}$, Ni'matush Sholikhah ${ }^{4}$, \\ Albrian Fiky Prakoso 5 \\ 1,2,3,4,5Jurusan Pendidikan Ekonomi, FE Universitas Negeri Surabaya \\ 5albrianprakoso@unesa.ac.id
}

\begin{abstract}
Abstrak
Pelatihan Penulisan Proposal Penelitian Tindakan Kelas (PTK) dilakukan kepada para guru MGMP IPS SMP Lamongan yang bertempat pada SMPN 1 Lamongan, JI. Ki Sarmidi Mangun Sarkara, Kelurahan Jetis, Kecamatan Lamongan, Jawa Timur. Tujuan Pelatihan dalam Pengabdian Kepada Masyarakat ini adalah untuk (1) memberikan penyampaian materi pada guru tentang Penelitian Tindakan Kelas (PTK), (2) memberikan penugasan penyusunan proposal pada guru tentang Penelitian Tindakan Kelas (PTK), (3) memberikan pendampingan pada guru tentang telaah proposal Penelitian Tindakan Kelas (PTK) yang telah dibuat oleh guru. Pelaksanaan PKM terdiri dari tahapan: 1) pemberian materi pelatihan terdiri: Hakekat Penelitian Tindakan Kelas (PTK), Anatomi Penelitian Tindakan Kelas (PTK), Metodologi Penelitian Tindakan Kelas (PTK), Grand Teori/ Kajian Teori dan Empirik, Penulisan proposal Penelitian Tindakan Kelas (PTK) oleh peserta; 2) Penyusunan proposal Penelitian Tindakan Kelas (PTK) oleh peserta; 3) Telaah proposal Penelitian Tindakan Kelas (PTK).
\end{abstract}

Kata Kunci: Proposal, Penelitian Tindakan Kelas

\begin{abstract}
Training of proposal writing Classroom Action Research was done to teachers Social Science MGMP of Lamongan at SMPN 1 Lamongan, road Ki Sarmidi Mangun Sarkara, Jetis, Lamongan, East Java. Purpose of this training to (1) provide the delivery of material for teachers on classroom action research, (2) gives the assignment of drafting a proposal for teachers on classroom action research, (3) provide assistance for teachers on study proposal Classroom action Research, which was created by the teacher. Implementation of PKM consists of stages: 1) the provision of training materials comprising: substance of Classroom Action Research, anatomy of a Classroom Action Research, Methodology of Classroom Action Research, grand theory / study of theory and empirical, writing proposals Classroom Action Research by participants; 2) Preparation of proposals Classroom Action Research by participants; 3) Review proposals Classroom Action Research.
\end{abstract}

Keywords: Proposal, Classroom Action Research

\section{PENDAHULUAN}

Berdasarkan Peraturan Menteri Negara Pendayagunaan Aparatur Negara dan Birokrasi Reformasi (PermenPAN) Nomor 16 Tahun 2009 Tentang Jabatan Fungsional Guru menjelaskan bahwa syarat kenaikan pangkat bagi guru menjadi golongan III-c ke atas, wajib membuat publikasi ilmiah dan atau karya inovatif. Publikasi ilmiah meliputi hasil penelitian atau gagasan inovatif pada bidang pendidikan formal; dan publikasi buku teks pelajaran, buku pengayaan, dan pedoman Guru. Sedangkan karya Inovatif meliputi menemukan teknologi tepat guna; menemukan/menciptakan karya seni; membuat/memodifikasi alat pelajaran/peraga/praktikum; dan mengikuti pengembangan penyusunan standar, pedoman, soal dan sejenisnya.

Menanggapi adanya kondisi tersebut, para guru IPS di tingkat Sekolah Menengah Pertama Kabupaten Lamongan yang tergabung dalam MGMP IPS SMP Lamongan yang diketuai oleh Drs. Wujud, M.Pd. membentuk jurnal ilmiah yang bernama 
"Jurnal Pembelajaran IPS". Jurnal Pembelajaran IPS merupakan jurnal yang mewadahi tulisan artikel ilmiah maupun penelitian ilmiah para guru di bidang keilmuan IPS. Jurnal Pembelajaran IPS yang terbentuk pada tahun 2014 dengan ketua redaksi Drs. Sukari, M.Pd. telah mampu terbit dua kali selama satu tahun, yakni pada bulan Februari dan Oktober.

Pada dua tahun perjalanannya, Jurnal Pembelajaran IPS mengalami kesulitan berupa kurang baiknya kualitas penulisan publikasi ilmiah, terutama pada penulisan PTK. Padahal sebagian besar guru yang telah lulus sertifikasi mendapatkan pelatihan pembuatan PTK ketika mengikuti PLPG. Namun, hal ini belum mampu mengantarkan guru yang tergabung di MGMP IPS SMP Lamongan dalam membuat artikel PTK yang baik.

PTK atau Penelitian Tindakan Kelas merupakan karya tulis ilmiah guru untuk perbaikan mutu PBM. Suharsimi Arikunto (2006) menjelaskan frasa penelitian tindakan kelas dari unsur kata pembentuknya, yakni penelitian, tindakan, dan kelas. Penelitian mengacu pada suatu kegiatan mencermati suatu objek dengan menggunakan cara atau aturan metodologi tertentu untuk memperoleh data atau informasi yang bermanfaat untuk meningkatkan mutu suatu hal yang menarik minat dan penting bagi peneliti. Tindakan mengacu pada suatu gerak kegiatan yang sengaja dilakukan dengan tujuan tertentu. Dalam penelitian tindakan kelas tindakan itu berbentuk rangkaian siklus kegiatan untuk siswa. Penelitian Tindakan Kelas merupakan penelitian yang lebih baik dilakukan oleh guru sebagai pelaksana program KBM di kelas. Sehingga, guru diharuskan menguasai keterampilan-keterampilan dalam Penelitian Tindakan Kelas (PTK).

Dengan menanggapi permasalah ini, maka diperlukan pelatihan lebih lanjut tentang "Pelatihan Penulisan Proposal Penelitian Tindakan Kelas (PTK)" kepada para guru MGMP IPS SMP Lamongan yang bertempat pada SMPN 1 Lamongan, Jl. Ki Sarmidi Mangun Sarkara, Kelurahan Jetis Kecamatan Lamongan, Lamongan Jawa Timur. Hal ini diperlukan untuk dapat menumbuhkan semangat para guru yang tergabung dalam MGMP IPS SMP Lamongan dalam menerbitkan tulisan ilmiah PTK dalam "Jurnal Pembelajaran IPS" secara kontinu.

Tujuan Pelatihan dalam Pengabdian Kepada Masyarakat ini adalah untuk (1) memberikan penyampaian materi pada guru tentang Penelitian Tindakan Kelas (PTK), (2) memberikan penugasan penyusunan proposal pada guru tentang Penelitian Tindakan Kelas (PTK), (3) memberikan pendampingan pada guru tentang telaah proposal Penelitian Tindakan Kelas (PTK) yang telah dibuat oleh guru.

\section{METODE PELAKSANAAN \\ Kerangka Pemecahan Masalah}

Rendahnya kualitas penulisan artikel ilmiah PTK yang diterbitkan oleh Jurnal Pembelajaran IPS dari tim MGMP IPS SMP Lamongan, membuat pentingnya dilaksanakan pendampingan penulisan proposal penelitian Tindakan Kelas (PTK). Berikut metode yang dilakukan:

1. Metode Pelaksanaan : ceramah bervariasi, praktek, diskusi dan tanya jawab.

2. Materi Pelatihan:
a. Hakekat Penelitian Tindakan Kelas (PTK)
b. Anatomi Penelitian Tindakan Kelas (PTK)
C. Metodologi Penelitian Tindakan Kelas (PTK)
d. Grand Teori/ Kajian Teori dan Empirik
e. Penulisan proposal Penelitian Tindakan Kelas (PTK) oleh peserta

3. Penyusunan proposal Penelitian Tindakan Kelas (PTK) oleh peserta

4. Telaah proposal Penelitian Tindakan Kelas (PTK)

Dalam rangka pemecahan masalah dapat digambarkan pada Gambar 1.

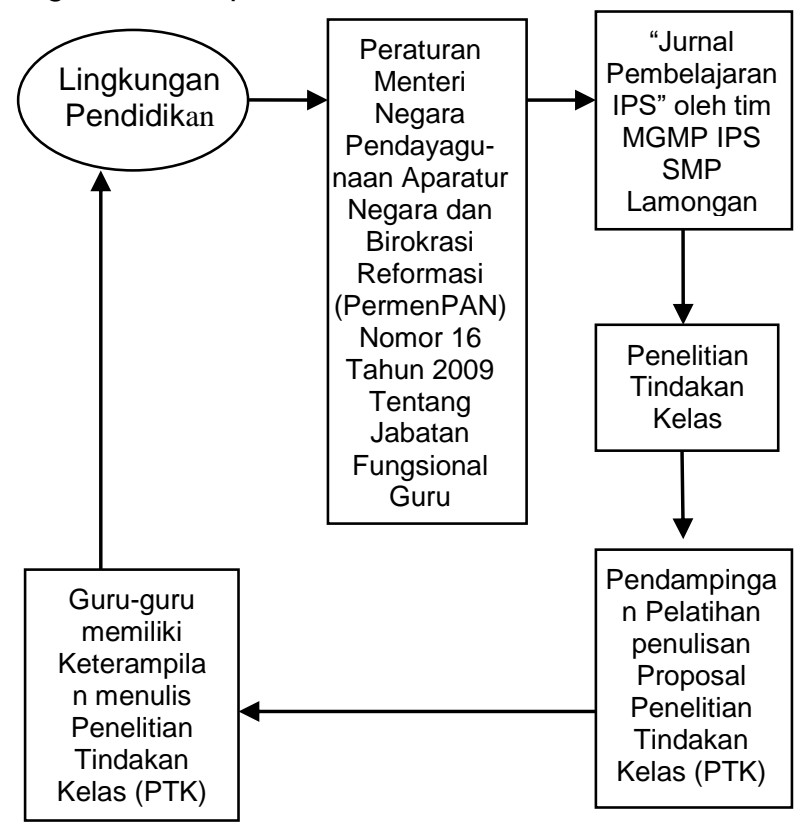

Gambar 1. Kerangka Pemecahan Masalah 


\section{Khalayak Sasaran}

Peserta pengabdian kepada masyarakat adalah guru SMP Se Kabupaten Lamongan. Peserta PKM dibatasi hanya \pm 20 orang yang tergabung dalam MGMP IPS SMP Lamongan.

\section{Keterkaitan}

Lembaga pengabdian masyarakat dan fakultas ekonomi telah membina hubungan melalui berbagai kesempatan Workshop serta pelatihan yang ada dalam usaha membina dan meningkatkan pola pemikiran serta pengetahuan guru-guru, khususnya untuk guru SMA yang tergabung dalam MGMP IPS SMP Lamongan.

\section{Metode Kegiatan PKM}

Kegiatan pengabdian kepada masyarakat dilakukan dengan cara mengadakan Penulisan Proposal Penelitian Tindakan Kelas (PTK). Adapun runtutan kegiatan PKM sebagai berikut:

1. Persiapan Sosialisasi Program

Program pengabdian kepada masyarakat disampaikan kepada sekolah, guru dan direspon positif. Selanjutnya kegiatan dikoordinasikan oleh Tim Pelaksana yaitu dengan cara menyampaikan informasi pelaksanaan Penulisan Penelitian Tindakan Kelas (PTK).

2. Pendataan Guru

Melakukan pendataan guru- guru yang mengikuti pelatihan Penulisan Penelitian Tindakan Kelas (PTK). Banyaknya guru peserta PKM \pm 20 orang yang tergabung dalam MGMP IPS SMP Lamongan.

3. Menyusun TIM pelaksana Pengabdian Masyarakat Tingkat Prodi.

Membentuk tim pelatihan proposal penelitian tindakan kelas, yang terdiri dari dosen-dosen Prodi Pendidikan Ekonomi yang mempunyai pengalaman dan keahlian di bidan PTK.

4. Pengajuan Proposal Pengabdian Masyarakat

Berdasarkan observasi kebutuhan sekolah tersebut, diajukan kegiatan pelatihan tindakan kelas untuk guru-guru yang tergabung dalam MGMP IPS SMP Lamongan dan kepada mitra sekolah SMPN 1 Lamongan.

5. Proposal diterima kemudian pelatihan dilaksanakan.

Pelatihan dilakukan dua periode: 1) penyampaian materi serta pemberian tugas pembuatan proposal PTK, dan 2) telaah proposal PTK oleh para peserta PKM. Dari hasil pelatihan ini, diharapkan menghasilkan luaran berupa proposal penelitian tindakan kelas.

\section{HASIL DAN PEMBAHASAN Deskripsi Hasil}

Kegiatan pengabdian kepada masyarakat ini dilaksanakan di SMPN 1 Lamongan yang beralamat di Jl. Ki Sarmidi Mangunsarkara 18 Lamongan. Kegiatan pengabdian kepada masyarakat ini dilakukan dalam bentuk pelatihan dengan metode ceramah dan praktek penulisan proposal PTK sebagai upaya untuk meningkatkan kemampuan guru guru-guru IPS SMP di Kabupaten Lamongan dalam menulis PTK dengan baik. Kegiatan ini ditujukan kepada guru MGMP IPS SMP di kabupaten Lamongan sejumlah 50 orang. Adapun data jumlah peserta pelatihan pada Tabel 1.

Tabel 1. Daftar Nama Peserta penulisan PTK guru-guru IPS SMP di Kabupaten Lamongan

\begin{tabular}{cll}
\hline No. & \multicolumn{1}{c}{ Nama } & \multicolumn{1}{c}{ Asal Sek } \\
\hline 1 & Sri Nawari Nugraheni, & SMPN 5 \\
& S.Pd. & Lamongan \\
2 & Yuni Indarwatiningsih, & SMPN 1 Su \\
\cline { 2 - 2 } & S.Pd, M.Pd
\end{tabular}

2 Yuni Indarwatiningsih, SMPN 1 Sugio S.Pd, M.Pd.

3 Sri Wahyuni, S.Pd. SMPN 3

4 Niken Purwaningtyas, SMPN 1 Glagah S.Pd.

5 Moh. Sya'roni, S.Pd. SMPN 1 Solokuro

6 Bondo, S.Pd. SMPN 1 Laren

7 Muh. Priyono, S.Pd. SMPN 1

8 Ninik Windartis, Kedungpring S.Pd. Karanggeneng

9 Muhamad Nur Cahyo, SMPN 1 Brondong S.Pd.

10 Rudy Subiyantoro SMPN 2 Mantup

11 Asykur Afandy, S.Pd. SMPN 1 Deket

12 Jafar

13 Zul Faidah, S.Pd.

14 Arin Yudiana, S.Pd., SMPN 4 Babat M.Pd.

15 Sutiani, S.Pd. SMPN 2 Sekaran

16 Mariyatul Badriyah, SMPN 2 S.Pd., M.Pd. Lamongan

17 Suharti, S.Pd. SMPN 2 Pucuk

18 Fifit Choiriyah, S.Pd. SMPN 1 Bluluk

19 Yenny Ermawati, S.P SMPN 1 Mantup

20 Khoiril Anwar, S.Pd., SMPN 3 Sugio M.Pd.

21 Budi Santosa, S.Pd., SMPN 1 Turi M.Pd. 


\begin{tabular}{lll}
\hline No. & \multicolumn{1}{c}{ Nama } & \multicolumn{1}{c}{ Asal Sekolah } \\
\hline 22 & Suwiyantoro, M.Pd. & SMPN 1 \\
& & Kembangbahu \\
23 & Buhadi Aziz, M.Pd. & SMPN 1 \\
& & Lamongan \\
24 & Sunarko, S.Pd. & SMPN 1 Sukodadi \\
25 & Nur Said & SMPN 1 Sarirejo \\
26 & Joko A, S.Pd. & SMPN 1 Ngimbang \\
27 & Drs. Akhmad Kholiq, & SMPN 4 \\
& M.Pd. & Lamongan \\
28 & Tri Winarni, S.Pd., & SMPN 1 Tikung \\
& M.Pd. & \\
29 & Dra. Ninik Eko Suyekti & SMPN 1 Sukodadi \\
30 & Sri Mulyani, S.Pd. & SMPN 5 \\
& & Lamongan \\
31 & Dra. Siti Ismarianah & SMPN 1 Sambeng \\
32 & Henny Chrismawati, & SMPN 2 Babat \\
& SE & \\
33 & Sri Rahayu, S.Pd. & SMPN 2 Modo \\
34 & Dra. Triana & SMPN 1 Babat \\
35 & Sri Rahayu Lestanti, & SMPN 2 Sukodadi \\
& S.Pd. & \\
36 & Luluk Umi Rukiyah, & SMPN 2 \\
& S.Pd., M.Pd. & Kedungpring \\
37 & Puji Wahono Harun Al & SMPN 1 \\
& Rasid & Karangbinangun \\
38 & Kunari & SMPN 2 \\
& Karangbinangun \\
39 & Drs. Tardi, M.Pd. & SMPN 2 Deket \\
40 & Drs. Wujud, M.Pd. & SMPN 2 Deket \\
41 & Sukari, S.Pd., M.Pd. & SMPN 1 Sukorame \\
42 & Sri Wahyuningsih, & SMPN 5 \\
& M.Pd. & Lamongan \\
43 & Dra. Dwi Meidiarti & SMPN 4 Babat \\
44 & Nurul Hidayati, M.Pd & SMPN 1 Paciran \\
45 & Atik Karmiati, S.Pd., & SMPN 2 \\
& M.Pd. & Lamongan \\
46 & Drs. Suud & SMPN 1 Pucuk \\
47 & Suparto, S.Pd. & SMPN 1 Pucuk \\
48 & Teguh Supriyanto & SMPN 1 Tikung \\
49 & Islani Budi L., S.Pd. & SMPN 1 Sukorame \\
50 & Nur'aini, S.Pd., M.Pd. & SMPN 2 Paciran \\
\hline Sumber: data diolah & \\
&
\end{tabular}

\section{Pemecahan Masalah Kegiatan Persiapan Pelatihan}

Sebelum melaksanakan kegiatan pelatihan, disusun terlebih dahulu materi untuk kegiatan PKM. Materi untuk pelatihan penulisan PTK didapatkan dari berbagai dokumen pemateri melalui berbagai kegiatan sebagai reviewer artikel ilmiah, seminar, dan pelatihan yang diikuti oleh pemateri. Materi untuk pelatihan PKM adalah:

a. Hakekat Penelitian Tindakan Kelas (PTK)

b. Anatomi Penelitian Tindakan Kelas (PTK)

c. Metodologi Penelitian Tindakan Kelas (PTK) d. Grand Teori/ Kajian Teori dan Empirik

e. Penulisan proposal Penelitian Tindakan Kelas (PTK)

f. Penyusunan proposal Penelitian Tindakan Kelas (PTK)

g. Telaah proposal Penelitian Tindakan Kelas (PTK)

1. Pelaksanaan pelatihan

Pada tahap pelaksanaan pelatihan penulisan

PTK dapat dirinci sebagai berikut:

Penyampaian Materi

Kegiatan pengabdian kepada masyarakat disampaikan kepada guru-guru MGMP IPS Kabupaten Lamongan dan memperoleh respon positif. Selanjutnya kegiatan dikoordinasikan oleh Tim Pelaksana yaitu dengan cara menyampaikan informasi pelaksanaan Pelatihan penulisan PTK. Pelaksanaan pelatihan dilakukan selama lima hari yaitu pada tanggal 30 Mei s.d 3 Juni 2016, dimana hari pertama sampai ketiga dilakukan on Class, hari keempat off class, dan hari kelima on Class. Pada hari pertama, ketua tim pelaksana sekaligus pemberi materi pertama dalam pelaksanaan pelatihan ini adalah Prof. Dr. Ady Soejoto, S.E,M.Si dengan materi Hakekat Penelitian Tindakan Kelas (PTK). Selanjutnya materi kedua disampaikan oleh Albrian Fiky P, S.Pd., M Pd dengan materi Anatomi Penelitian Tindakan Kelas (PTK).

Pada hari kedua, materi dilanjutkan oleh Dhiah Fitrayati, S.Pd., M.E dengan materi Metodologi Penelitian Tindakan Kelas (PTK). Setelah selesai penyampaian materi oleh Dhiah Fitrayati, S.Pd., M.E materi dilanjutkan oleh Ni'matush Sholikhah, S.Pd., M.Pd dengan materi Grand Teori/ Kajian Teori dan Empirik.

Pada hari ketiga, materi dilanjutkan oleh M. Abdul Ghofur, S.E., M.Pd dengan materi Penulisan proposal Penelitian Tindakan Kelas (PTK) setelah itu dibuka sesi tanya jawab. Keesokan harinya yaitu hari keempat, pelatihan dilakukan off class, dimana semua peserta diminta untuk menyusun proposal secara mandiri dirumah masing-masing.

Sebelum kegiatan off class dilaksanakan, terlebih dahulu peserta dibagi menjadi 5 kelompok. Kelompok 1 dengan Prof. Dr. Ady Soejoto, S.E, M.Si, kelompok 2 dengan Albrian Fiky P, S.Pd., M Pd, kelompok 3 dengan Dhiah Fitrayati, S.Pd., kelompok 4 dengan M.E Ni'matush Sholikhah, S.Pd., M.Pd dan kelompok 5 dengan M. Abdul Ghofur, S.E., M.Pd. Pada masing-masing kelompok terdiri dari 10 orang peserta. 
Setelah peserta selesai menyusun proposal, maka setiap peserta mengirim proposal tersebut melalui e-mail ke masingmasing pemateri yang telah dibagi sebelumnya. Keesokan harinya yaitu hari kelima para pemateri mereview proposal yang telah dikirim oleh peserta, kemudian semua tim menelaah dan peserta memperbaiki proposal masing-masing sesuai dengan masukan yang telah diberikan oleh pemateri pada masing-masing kelompok. Selanjutnya hasil review masing-masing kelompok dipresentasikan.

\section{Ruang Pelaksanaan Pelatihan}

Tabel 2. Rekapitulasi Persepsi Guru MGMP IPS SMP Kabupaten Lamongan tentang pelatihan

penulisan PTK

\begin{tabular}{|c|c|c|c|c|c|c|c|}
\hline \multirow[b]{2}{*}{ No. } & \multirow[b]{2}{*}{ Uraian } & \multicolumn{5}{|c|}{ Kriteria } & \multirow[b]{2}{*}{$\begin{array}{l}\text { Jum- } \\
\text { lah }\end{array}$} \\
\hline & & $\begin{array}{c}\text { Sangat } \\
\text { Puas }\end{array}$ & Puas & Cukup & $\begin{array}{l}\text { Tidak } \\
\text { Puas }\end{array}$ & $\begin{array}{c}\text { Sangat } \\
\text { Tidak Puas }\end{array}$ & \\
\hline & Pelayanan Panitia PKM & & & & & & \\
\hline 1 & Kondisi tempat/ruang pelatihan & 29 & 21 & 0 & 0 & 0 & 50 \\
\hline 2 & $\begin{array}{l}\text { Kondisi sarana-prasaranadalam } \\
\text { pelatihan }\end{array}$ & 21 & 29 & 8 & 0 & 0 & 50 \\
\hline 3 & $\begin{array}{l}\text { Penguasaan materi oleh instruktur } \\
\text { pelatihan }\end{array}$ & 20 & 30 & 2 & 0 & 0 & 50 \\
\hline 4 & $\begin{array}{l}\text { Pemberian kesempatan dalam } \\
\text { bertanya }\end{array}$ & 23 & 27 & 4 & 0 & 0 & 50 \\
\hline \multirow[t]{4}{*}{5} & Layanan panitia selama pelatihan & 15 & 35 & 10 & 0 & 0 & 50 \\
\hline & Rata-rata & 21,6 & 28,4 & 4,8 & 0 & 0 & 50 \\
\hline & & $\begin{array}{l}\text { Sangat } \\
\text { Sesuai }\end{array}$ & Sesuai & Cukup & $\begin{array}{l}\text { Kurang } \\
\text { Sesuai }\end{array}$ & $\begin{array}{l}\text { Tidak } \\
\text { Sesuai }\end{array}$ & \\
\hline & Relevansi Materi & & & & & & \\
\hline \multirow[t]{2}{*}{6} & $\begin{array}{l}\text { Relevansi materi pelatihan yang } \\
\text { diberikan dengan mata pelajaran }\end{array}$ & 15 & 30 & 4 & 1 & 0 & 50 \\
\hline & & $\begin{array}{c}\text { Sangat } \\
\text { Jelas }\end{array}$ & Jelas & Cukup & $\begin{array}{c}\text { Kurang } \\
\text { Jelas }\end{array}$ & Tidak Jelas & \\
\hline \multirow[t]{2}{*}{7} & $\begin{array}{l}\text { Kejelasan Penyampaian Materi oleh } \\
\text { Instruktur } \\
\text { Kejelasan dalam penyampaian oleh } \\
\text { instruktur pelatihan }\end{array}$ & 15 & 28 & 7 & 0 & 0 & 50 \\
\hline & & $\begin{array}{c}\text { Sangat } \\
\text { Sistematis }\end{array}$ & Sistematis & Cukup & $\begin{array}{l}\text { Kurang } \\
\text { siste- } \\
\text { matis }\end{array}$ & $\begin{array}{c}\text { Tidak } \\
\text { Sistematis }\end{array}$ & \\
\hline \multirow{3}{*}{8} & Sistematika Penyampaian Materi & 22 & 26 & 2 & 0 & 0 & \\
\hline & $\begin{array}{l}\text { Sistematika (urut-urutan) penyampaian } \\
\text { materi pelatihan }\end{array}$ & & & & & & 50 \\
\hline & & $\begin{array}{l}\text { Sangat } \\
\text { Penting }\end{array}$ & Penting & Cukup & $\begin{array}{l}\text { Kurang } \\
\text { penting }\end{array}$ & $\begin{array}{c}\text { Tidak } \\
\text { Penting } \\
\end{array}$ & \\
\hline \multirow[t]{2}{*}{9} & $\begin{array}{l}\text { Menurut Bapak/lbu, materi yang } \\
\text { diberikan dalam pelatihan ini }\end{array}$ & 18 & 28 & 4 & 0 & 0 & 50 \\
\hline & & $\begin{array}{l}\text { Sangat } \\
\text { Setuju }\end{array}$ & Setuju & $\begin{array}{l}\text { Biasa } \\
\text { saja }\end{array}$ & $\begin{array}{l}\text { Kurang } \\
\text { Setuju }\end{array}$ & $\begin{array}{l}\text { Tidak } \\
\text { Setuju }\end{array}$ & \\
\hline 10 & $\begin{array}{l}\text { Pentingnya Materi yang diberikan } \\
\text { Kegiatan pelatihan semacam ini perlu }\end{array}$ & 22 & 28 & 0 & 0 & 0 & 50 \\
\hline
\end{tabular}

Pelaksanaan pelatihan bertempat di Aula gedung SMPN 1 Lamongan. Peserta yang mengikuti pelatihan ini adalah Guru MGMP IPS SMP Kabupaten Lamongan yang dipertemukan dalam satu ruang. Penjelasan dan pemaparan dilakukan melalui metode ceramah, demonstasi, dan praktik penulisan proposal PTK sesuai dengan permasalahan dan materi yang telah dirancang.

Berdasarkan hasil komunikasi dengan Guru MGMP IPS SMP se Kabupaten Lamongan, maka didapatkan hasil angket persepsi Guru MGMP IPS SMP Kabupaten Lamongan tentang pelatihan penulisan PTK seperti pada dalam Tabel 2 . 


\begin{tabular}{|c|c|c|c|c|c|}
\hline & $\begin{array}{l}\text { diteruskan pada waktu yang akan data } \\
\text { dengan materi yang lain }\end{array}$ & & & & \\
\hline & & Ya & Ragu-ragu & Tidak & \\
\hline 11 & $\begin{array}{l}\text { Keberlanjutan Kegiatan } \\
\text { Setelah mendapatkan pelatihan ini, } \\
\text { apakah Bapak/lbu berkeinginan untuk } \\
\text { menulis PTK }\end{array}$ & 49 & 1 & 0 & 50 \\
\hline
\end{tabular}

Sumber: data diolah (2016)

Untuk memudahkan membaca rekapitulasi angket peserta pelatihan penulisan PTK, maka dibuat grafik. Grafik yang pertama yaitu tentang pelayanan panitia PKM yaitu sebagaimana Gambar 2:

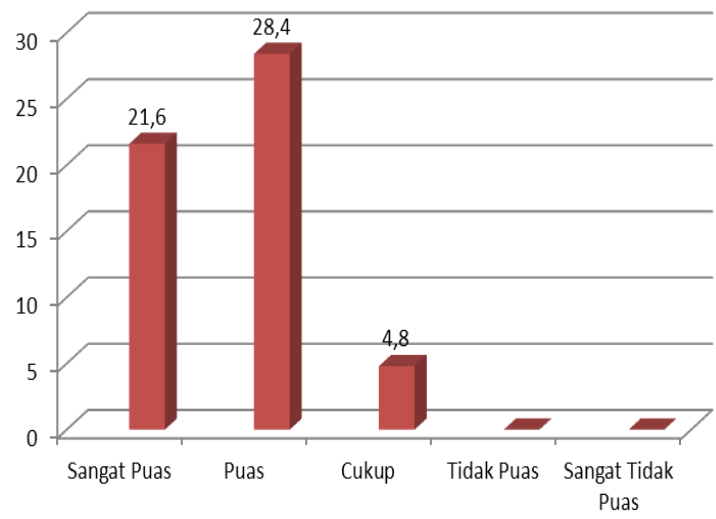

Gambar 2. Pelayanan Panitia PKM

Berdasarkan hasil angket yang dibagikan pada peserta, maka didapatkan hasil untuk rata-rata pelayanan Panitia PKM, peserta menyatakan sangat baik sebanyak $21,6 \%$, puas sebanyak $28,4 \%$, dan cukup sebanyak $4,8 \%$. Secara keseluruhan untuk layanan panitia kepada peserta merasa sangat puas dan puas atas pelayanan yang diberikan panitia.

Respon peserta pelatihan penulisan PKM berikutnya yaitu tentang relevansi materi yang telah disampaikan oleh pemateri. Grafik respon relevansi materi ditampilkan sebagai berikut.

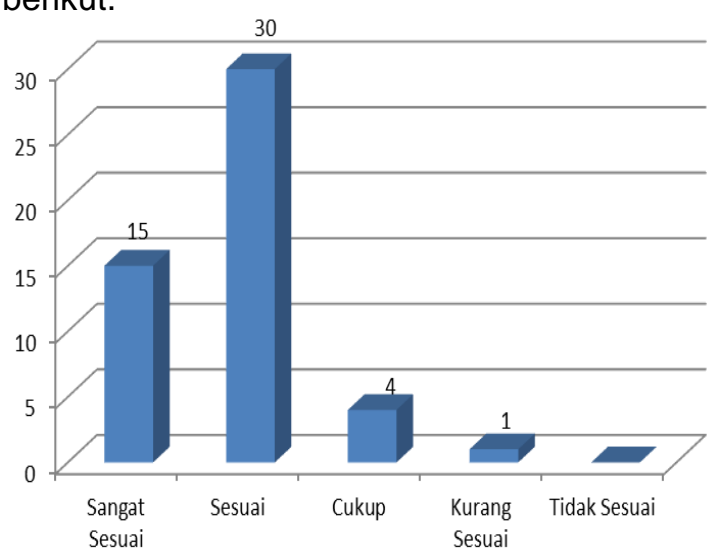

Gambar 3. Relevansi Materi
Berdasarkan Gambar 3, dapat dilihat bahwa respon peserta terhadap pelatihan pengelolaan jurnal menggambarkan bahwa peserta menyatakan materi yang diberikan sangat sesuai sebanyak 15 orang, sesuai sebanyak 30 orang, cukup sebanyak 4 orang dan kurang sesuai sebanyak 1 orang. Hal ini dikarenakan pentingnya penulisan PTK untuk guru-guru yang dapat dipergunakan untuk kenaikan pangkat dan meningkatkan kredibelitas mereka

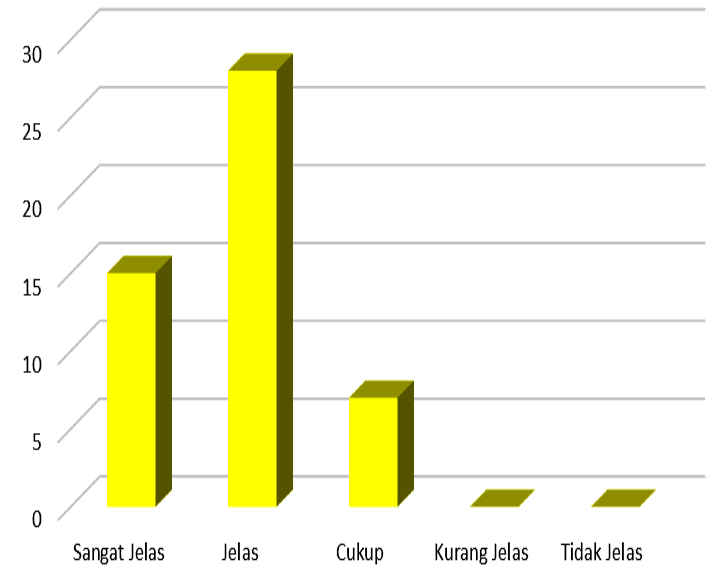

Gambar 4. Kejelasan Penyampaian Materi oleh Instruktur

Berkenaan dengan kejelasan materi yang diberikan oleh Instruktut/ pemateri, dapat dilihat dari Gambar 4 bahwa sebanyak 15 orang peserta merasa sangat jelas, 28 orang peserta merasa jelas, sebanyak 7 orang merasa cukup dan sisanya 0 .

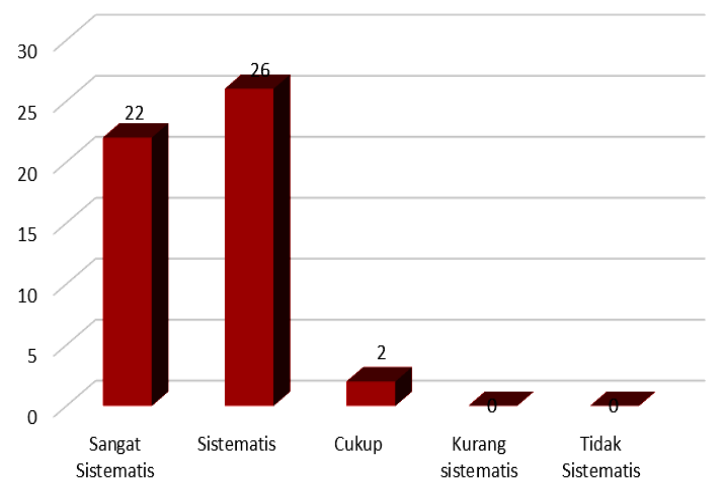

Gambar 5. Sistematika penyampaian Materi 
Berdasarkan Gambar 5 dapat diketahui bahwa peserta merasa materi yang diberikan sangat sistematis sebanyak 22 orang, sistematis sebanyak 26 orang, cukup sebanyak 2 orang, dan sisanya 0 .

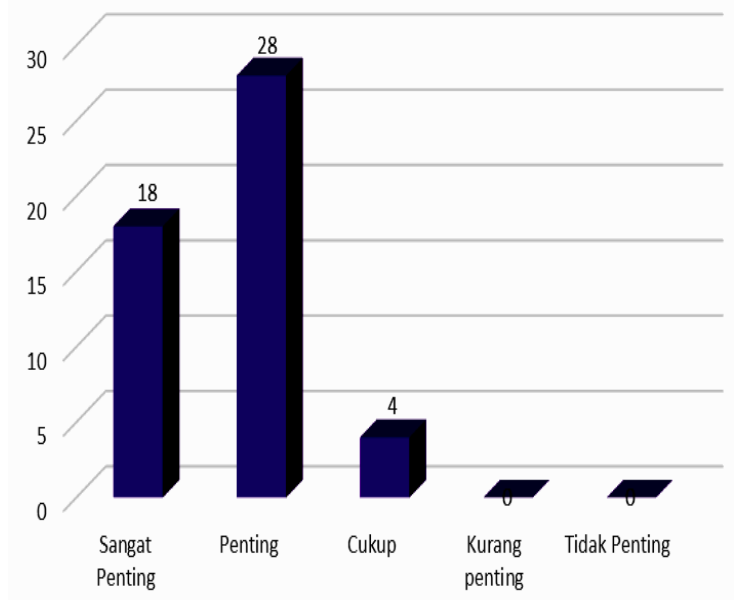

Gambar 6. Pentingnya materi yang diberikan

Pertanyaan ini diberikan kepada peserta untuk mengetahui penting tidaknya materi yang diberikan kepada peserta. Dengan demikian materi yang disampaikan oleh instruktur dirasa oleh peserta yaitu sangat penting sebanyak 18 orang, merasa penting 28 orang, cukup penting sebanyak 4 orang, dan sisanya 0 (Gambar 6).

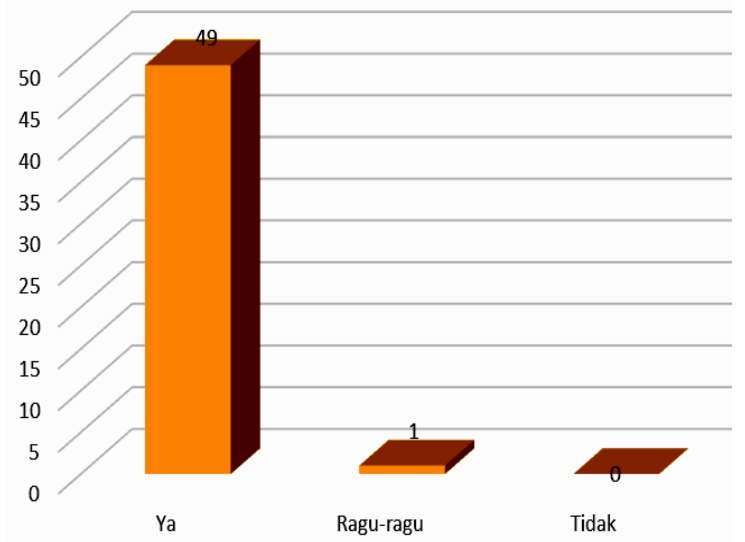

Gambar 7. Keberlanjutan kegiatan

Berdasarkan Gambar 7 di atas dapat diketahui bahwa respon peserta terhadap keberlanjutan program pelatihan penulisan
PTK untuk dilanjutkan sebanyak 49 orang sangat setuju, dan ragu-ragu sebanyak 1 orang. Dengan demikian secara keseluruhan persepsi guru MGMP IPS SMP se Kabupaten Lamongan terhadap pelatihan yang diberikan baik dan perlu diadakan kegiatan lanjutan atau yang kontinyu kepada penulisan laporan PTK agar kualitas pembelajaran dan profesionalitas guru dapat meningkat.

\section{Pembimbingan}

Proses pembimbingan dilaksanakan selama pelatihan berlangsung yaitu pada hari terakhir atau hari kelima. Guru MGMP IPS SMP Kabupaten Lamongan dibantu untuk menyusun proposal PTK sesuai dengan format yang telah diberikan Instruktur pada hari sebelumnya. Pembimbingan lebih lanjut dilakukan pada latar belakang permasalahan penelitian, teori, dan sintaks model pembelajaran. Peserta sangat antusias dalam mengikuti proses pembimbingan ini, hal ini ditandai setiap pembimbingan selalu diikuti oleh peserta secara penuh.

\section{Evaluasi Pelaksanaan Pelatihan}

Untuk melakukan evaluasi pelaksanaan pelatihan penulisan PTK, maka tim PKM menyebarkan angket yang telah dianalisis di atas. Selanjutnya hasil penulisan proposal PTK yang telah dibuat oleh peserta pelatihan direview Instruktur pelatihan dan akhirnya dipresentasikan untuk dievaluasi bersama.

\section{Luaran}

Dari hasil yang didapat maka luaran yang dicapai pada PKM ini dibuktikan dengan proposal PTK yang telah dibuat oleh peserta PKM. Dari 50 peserta yang hadir, hanya 24 peserta atau sikitar $50 \%$ saja yang selesai membuat proposal PTK. Namun, dari ke 24 peserta tersebut terdapat beberapa peserta membuat PTK yang ideal dalam artian sesuai dengan sistematika PTK yang diinginkan oleh pemateri. Rincian hasil proposal PTK yang dibuat peserta yaitu sebagaimana disajikan pada Tabel 3.

Tabel 3. Rincian Proposal PTK oleh Peserta

\begin{tabular}{|c|l|c|c|c|c|c|}
\hline \multirow{2}{*}{ No. } & \multirow{2}{*}{ Nama Peserta } & \multicolumn{3}{|c|}{$\begin{array}{c}\text { Kesesuaian } \\
\text { Sistematika }\end{array}$} & \multicolumn{2}{c|}{ Relevansi } \\
\cline { 3 - 7 } & & Bab 1 & Bab 2 & Bab 3 & Teori & $\begin{array}{c}\text { Penelitian } \\
\text { Terdahulu }\end{array}$ \\
\hline 1 & Sukari, M.Pd & $\sqrt{ }$ & $\sqrt{ }$ & $\sqrt{ }$ & $\sqrt{ }$ & $\sqrt{ }$ \\
\hline 2 & Sri Nawari, S.Pd & $\sqrt{ }$ & $\sqrt{ }$ & $\sqrt{ }$ & $\sqrt{ }$ & $\sqrt{ }$ \\
\hline
\end{tabular}




\begin{tabular}{|c|l|c|c|c|c|c|}
\hline \multirow{2}{*}{ No. } & \multicolumn{2}{|c|}{ Nama Peserta } & \multicolumn{3}{c|}{$\begin{array}{c}\text { Kesesuaian } \\
\text { Sistematika }\end{array}$} & \multicolumn{2}{c|}{ Relevansi } \\
\cline { 3 - 7 } & & Bab 1 & Bab 2 & Bab 3 & Teori & $\begin{array}{c}\text { Penelitian } \\
\text { Terdahulu }\end{array}$ \\
\hline 3 & Sri Wahyuni, S.Pd & $\sqrt{ }$ & - & - & - & - \\
\hline 4 & Asykur Afandy, S.Pd & $\sqrt{ }$ & $\sqrt{ }$ & $\sqrt{ }$ & $\sqrt{ }$ & $\sqrt{ }$ \\
\hline 5 & Arin Yudiana, S.Pd, M.Pd & $\sqrt{ }$ & $\sqrt{ }$ & - & $\sqrt{ }$ & - \\
\hline 6 & Mariyatul B, S.Pd, M.Pd & $\sqrt{ }$ & - & - & - & - \\
\hline 7 & Khoiril A, S.Pd, M.Pd & $\sqrt{ }$ & - & - & - & - \\
\hline 8 & Budi Santosa, S.Pd, M.Pd & $\sqrt{ }$ & $\sqrt{ }$ & - & $\sqrt{ }$ & - \\
\hline 9 & Suwiyantoro, M.Pd & $\sqrt{ }$ & $\sqrt{ }$ & - & $\sqrt{ }$ & $\sqrt{ }$ \\
\hline 10 & Buhadi Aziz, M.Pd & $\sqrt{ }$ & $\sqrt{ }$ & $\sqrt{ }$ & $\sqrt{ }$ & - \\
\hline 11 & Drs. Akhmad, M.Pd & $\sqrt{ }$ & - & - & - & - \\
\hline 12 & Tri Winarni, S.Pd, M.Pd & $\sqrt{ }$ & $\sqrt{ }$ & $\sqrt{ }$ & $\sqrt{ }$ & $\sqrt{ }$ \\
\hline 13 & Luluk, S.Pd, M.Pd & $\sqrt{ }$ & $\sqrt{ }$ & $\sqrt{ }$ & $\sqrt{ }$ & $\sqrt{ }$ \\
\hline 14 & Drs. Tardi, M.Pd & $\sqrt{ }$ & $\sqrt{ }$ & - & $\sqrt{ }$ & - \\
\hline 15 & Drs. Wujud, M.Pd & $\sqrt{ }$ & $\sqrt{ }$ & - & $\sqrt{ }$ & - \\
\hline 16 & Sri W, M.Pd & $\sqrt{ }$ & $\sqrt{ }$ & - & $\sqrt{ }$ & $\sqrt{ }$ \\
\hline 17 & Nurul Hidayati, M.Pd & $\sqrt{ }$ & - & - & - & - \\
\hline 18 & Atik K, S.Pd, M.Pd & $\sqrt{ }$ & - & - & - & - \\
\hline 19 & Drs. Suud & $\sqrt{ }$ & $\sqrt{ }$ & - & $\sqrt{ }$ & $\sqrt{ }$ \\
\hline 20 & Suparto, S.Pd & $\sqrt{ }$ & - & - & - & - \\
\hline 21 & Teguh Supriyanto, S.Pd & $\sqrt{ }$ & $\sqrt{ }$ & - & $\sqrt{ }$ & - \\
\hline 22 & Islani Budi L, S.Pd & $\sqrt{ }$ & - & - & - & - \\
\hline 23 & Nur'aini, S.Pd, M.Pd & $\sqrt{ }$ & $\sqrt{ }$ & $\sqrt{ }$ & $\sqrt{ }$ & $\sqrt{ }$ \\
\hline 24 & Asykur Afandy, S.Pd & $\sqrt{ }$ & $\sqrt{ }$ & - & $\sqrt{ }$ & - \\
\hline Sunyyyyyy & & & & & \\
\hline
\end{tabular}

Sumber: Data diolah (2016)

Dari Tabel 3 di atas dapat diketahui bahwa hanya terdapat 6 peserta yang membuat PTK sesuai dengan sistematika PTK yang diminta oleh pemateri. Rata-rata peserta yang mengumpulkan adalah peserta dengan tingkat pendidikan S2. Tetapi juga tidak dipungkiri peserta yang bergelar S1 juga dapat membuat proposal PTK. Disisi lain peserta yang bergelar S1 Drs atau Dra hanya satu peserta. Setelah dilakukan wawancara oleh beberapa peserta yang tidak membuat PTK, mereka mengaku bahwa mereka merasa sudah tua dan sudah tidak mapu lagi untuk melakukan penelitian, tetapi mereka tetap memiliki antusiasme yang sangat besar dalam pengikuti kegiatan PKM.

Sedangkan pada tingkat kesesuaian sistematika proposal PTK yang telah dibuat oleh peserta terkait dengan kesulitan peserta dalam mencari teori yang relevan dan juga penelitian terdahulum. Mereka mengaku bahwa mereka measa kesulitan mencari model pembelajaran yang sesuai dengan materi yang akan mereka gunakan sebagai penelitian. Selain itu peserta juga merasa kesulitan mencari artikel Ilmiah (Jurnal) yang relevan dengan judul yang mereka usulkan. Dengan demikian terdapat juga peserta yang hanya membuat Bab 1 (latar belakang) saja dan ada juga yang membuat bab 1 hingga bab 3 namun mereka tidak mencantumkan penelitian terdahulu.

\section{SIMPULAN DAN SARAN}

Pengetahuan yang telah diterima oleh peserta pelatihan PTK adalah Pengetahuan dasar tentang ' Teknik penulisan PTK yang baik', dilanjutkan dengan praktek penulisan proposal PTL dan pendampingan mereview proposal PTK.

Guru MGMP IPS SMP se Kabupaten Lamongan juga memiliki kemauan untuk dapat meningkatkan potensi diri dan mengembangkan khasanah keilmuannya. Kemauan ini timbul dengan indikasi antusiasme yang besar dari peserta pelatihan dalam mengikuti semua tahapan pelatihan.

Secara keseluruhan persepsi peserta pelatihan tentang layanan yang diberikan oleh panitia PKM berkategori baik dan perlu diadakan lagi kegiatan pada tahap lebih lanjut dan tentunya juga berhubungan dengan peningkatan kredibelitas guru, agar kinerja guru dan kualitas pembelajaran yang diberikan oleh guru dapat meningkat.

Untuk meningkatkan pemahaman terhadap materi pelatihan penulisan proposal 
PTK yang diberikan, maka perlu dilakukan pembimbingan dan praktek yang berkelanjutan. Disi lain, kegiatan ini juga memerlukan dukungan dari lembaga terkait untuk memfasilitasi guru-guru dalam mengakses informasi berkenaan dengan teori pembelajaran dan teknik penulisan PTK yang akan dipakai untuk menyusun proposal PTK yang dilakukan oleh guru.

\section{DAFTAR PUSTAKA}

Ali, Mohamad.1985. Penelitian Kependidikan Prosedur dan Strategi. Angkasa. Bandung: Angkasa.

Anwar, 2006. Penggunaan Pete Konsep Melalui Model Pembelajaran KooperatifTipe STAD Untuk Meningkatkan Proses, Hasl belajar dan Respon pada Konsep Ekosistem Siswa Kelas X SMAN 8 Malang. Tesis tidak diterbaitkan. Malang: Universitas Negeri Malang. PPS Biologi.

Aqib, Zainal. 2002. Profesionalisme Guru dalam Pembelajaran. Surabaya: Insan Cendekia.

Arikunto, Suharsimi dkk. 2007. Penelitian Tindakan Kelas. Jakarta: PT Bumi Aksara.
Bohar, Soeharto. 1985. Menyiapkan Penelitian dan Penulisan Karya Ilmiah (Skripsi-Thesis). Bandung: Tarsito.

Dimyati \& Mudjiono. 2002. Belajar dan Pembelajaran. Jakarta: Rineka Cipta.

Djamarah, Syaiful Bahri. 2005. Guru dan Anak Didik dalam Interaksi Edukatif Suatu Pendekatan Teoritis Psikologis. Jakarta: Rineka Cipta.

Dwiloka, Bambang. 2005. Teknik Menulis Karya IImiah. Bandung: Rineka Cipta.

Elfitri, Ayu Rahayu. 2012. Kompas

Hamalik, Oemar. 2001. Proses Belajar Mengajar. Jakarta: Bumi Aksara.

Hariwijaya. 2008. Pedoman Penulisan IImiah proposal dan Skripsi. Tugu Publisher.

Hasan, dkk. 2003. Metodologi Penelitian Kualitatif Tinjauan Teoritis dan Praktis. Malang: Lembaga Penelitian UNISMA kerjasama dengan VISIPRESS.

Moleong, L. J. 2002. Metodologi Penelitian Kualitatif. Bandung: PT Remaja Rosdakarya.

Mulyasa. 2003. Kurikulum Berbasis Kompetensi. Bandung: Remaja Rosdakarya. 